\title{
Study of Blood Iron and vs. Blood Lead Levels in Beta-Thalassemia Patients in Turkey: An Application of Analytical Toxicology
}

\author{
Bayram Yüksel*, Dilek Kaya-Akyüzlü, Zeliha Kayaalti*, \\ Fezile Özdemir, Derya Söylemez-Gökyer, and Tülin Söylemezoglu \\ Ankara University, Institute of Forensic Sciences, Dikimevi 06590, Ankara, Turkey
}

\section{INTRODUCTION}

Beta-thalassemia is a disorder caused by a deficiency of beta globin related to any of more than 200 point mutations in functionally important regions of the beta globin gene on chromosome 11 (1). This deficiency brings about an accumulation of unpaired $\alpha$-globin chains and an inequality between $\alpha$ and $\beta$ globin chains that develop an extensive range of thalassaemia phenotypes, including severe anemia and clinically asymptomatic individuals (2). Individuals suffering from thalassemia major need periodic and life-long red blood cell transfusions to prevent anemia, blocking the ineffective erythropoiesis, inhibiting the gastrointestinal iron absorption, and maintaining adequate oxygen delivery to the tissues (3). Nevertheless, repeated blood transfusions contribute progressive systemic iron overload which leads not only to elevated tissue iron but also to increased non-transferrin-bound iron which is highly toxic because of the formation of reactive oxygen species and the generation of peroxidative tissue injury (4).

Trace amounts of iron are essential elements for many biological and cellular processes, and are part of numerous hemoproteins and non-heme iron proteins (5).

Furthermore, iron can be toxic by catalyzing the production of oxygen radicals through the Fenton or Haber-Weiss reactions when iron exists in excess and/or is not tightly

Corresponding autbors.

E-mail: bayramyuksel83@gmail.com

Tel/Fax: +90 5056283792

E-mail: zkayati@gmail.com

Tel: +905053663848

\section{ABSTRACT}

The main goal and novelty of this paper was to assess the blood iron and lead levels of betathalassemia patients vs. healthy (non-thalassemic) control subjects. The study involved 100 genetically unrelated thalassemia patients and 100 healthy unrelated controls. The blood lead levels were measured by graphite furnace atomic spectrometry and the blood iron levels were measured by flame atomic absorption spectrometry. The mean blood iron level was found to be significantly lower in beta-thalassemia patients $(293.20 \pm 58.49 \mathrm{mg} / \mathrm{L})$ than in the controls $(405.28 \pm 11.14 \mathrm{mg} / \mathrm{L})$ $(\mathrm{p}<0.05)$. On the other hand, the mean blood lead level was significantly higher in beta-thalassemia patients $(71.20 \pm 43.38 \mu \mathrm{g} / \mathrm{L})$ than those in the controls $(27.58 \pm 8.18$ $\mu \mathrm{g} / \mathrm{L})(\mathrm{p}<0.05)$. A statistically negative correlation between iron and lead was found in the beta-thalassemia patients $(r=-0.424, p<0.05)$. This study revealed that iron deficiency in beta-thalassemia patients is associated with higher blood lead levels.

bound to specialized proteins such as transferrin and ferritin (6). For this reason, various proteins such as transferrin (TF) control the intracellular iron content firmly while avoiding iron overload (7). In normal individuals, the majority of total body iron is incorporated into hemoglobin of the erythroid cells in the reticuloendothelial macrophages and in the myoglobin of muscles. Excess iron is stored in the liver since the body has no effective way to remove the iron (8).

Lead $(\mathrm{Pb})$ is the 5 th most abundant metal in the earth's crust (9). Moreover, it is a cumulative, environmental, and occupational toxic substance (10). Lead has no beneficial function in humans, and exposure can occur through food, contaminated air and dust, is transported and bound to erythrocytes, and accumulates in the bones with a half-life of around 30 years (11, 12). Lead compounds and inorganic $\mathrm{Pb}$ were classified as "Group $2 \mathrm{~A}$ probably carcinogenic to humans" by the International Agency for Research on Cancer (IARC) in 2006 (13). The metal also has serious effects on the nervous, circulatory, skeletal, renal, hematopoietic, and endocrine systems, and toxicity inhibits sulfhydryl-dependent enzymes or induces oxidative stress (14).

Various studies have been published regarding hematological analysis and the metal levels in beta-thalassemia patients. Ferdaus et al. (2010) analyzed the metal ion levels of $\mathrm{Zn}, \mathrm{Cu}$, and $\mathrm{Mg}$ in betathalassaemic children from Bangladesh (15). Uddin et al. (2012) also performed hematological analysis in beta-thalassemia patients in Bangladesh (16). Karim et al. (2016) evaluated some of the essential trace element levels in beta-thalassemia major patients and controls, and reported that the serum iron value in these patients was close to the control values due to an oral iron chelating drug (17). Kumfu et al. (2016) studied the effects of iron overload conditions on liver toxicity and hepcidin/ferroportin expression in thalassemic mice (18). 
According to literature research by the present authors, there is limited information available concerning the correlation between blood lead and iron levels in non-exposed individuals or in healthy controls. No comparative analysis of blood lead and iron in beta-thalassemia patients of the Turkish population has been previously assessed. For this reason, the present study is intended to measure blood iron and lead levels in 100 genetically unrelated thalassemia patients and 100 healthy unrelated controls. It is, therefore, the first investigation into establishing whether or not iron deficiency in Turkish betathalassemia patients is associated with blood lead levels.

\section{EXPERIMENTAL}

\section{Instrumentation}

Blood lead levels were quantified using a Varian AA 240 Z Zeeman graphite furnace atomic absorption spectrometer (GFAAS) (Victoria, Australia), while blood iron levels were measured with a Varian AA 240 FS flame AAS (Victoria, Australia). Boosted discharge hollow cathode lamps (Agilent, Australia) were used for the excitation source for lead and iron.

\section{Standard Solutions and Reagents}

Stock solutions of $1000 \mu \mathrm{g} / \mathrm{mL}$ lead and iron were obtained from SCP Science AA Standards (Canada). Nitric acid $\left(\mathrm{HNO}_{3}, 65 \%\right.$ v:v) and ammonium dihydrogen phosphate were purchased from Merck (Darmstadt, Germany). All chemicals used for the laboratory process were of analytical reagent grade. Ultrapure water (Merck Millipore $^{\circledR}$ Direct-Q8, Germany) with a resistivity of $18 \mathrm{M} \Omega \cdot \mathrm{cm}$ was utilized to prepare the solutions for the experimental study. Argon gas with a purity of $99.999 \%$ was purchased from a local supplier (Vasak Gaz, Ankara, Turkey). The reference material used for validation of the method was Seronorm $^{\text {TM }}$ Trace Elements Whole Blood L-2 (Sero AS., Billingstad, Norway).

\section{Sample Collection and Study Subjects}

The study population involved 100 genetically unrelated thalassemia patients (average age: $28.44 \pm 9.36$ years) and 100 healthy unrelated controls (average age: $31.88 \pm 5.72$ years) who had no known illness that would interact with their blood metal levels. Two $\mathrm{mL}$ of venous blood sample was drawn from each subject into tubes with EDTA (for transfusion-dependent thalassemia patients, just before transfusion) and stored at $4^{\circ} \mathrm{C}$ in the refrigerator. This study was ethically approved by the Research Ethics Committee of the Medical Faculty, Ankara University (Approval No. 07-286-13/2013). Each volunteer was given a written informed consent form in accordance with the principles as established by the World Medical Association, Declaration of Helsinki, in 1964 .

\section{Procedure}

To prepare the calibration standards at the concentrations of 5.0, $10.0,15.0$, and $20.0 \mu \mathrm{g} / \mathrm{L}$, a 1000$\mu \mathrm{g} / \mathrm{mL}$ lead stock solution was diluted in $4 \%$ (v:v) $\mathrm{HNO}_{3}$. Similarly, a $1000-\mu \mathrm{g} / \mathrm{mL}$ iron stock solution was diluted in $4 \%$ (v:v) $\mathrm{HNO}_{3}$ to prepare the calibration standards at the concentrations of 2.0, 4.0, 8.0, $12.0 \mathrm{mg} / \mathrm{L}$ for iron analysis. Calibration graphs for lead and iron are shown in Figures 1 and 2, respectively. Prior to the analysis, 1-mL amounts of blood sample were dissolved in $10 \mathrm{~mL}$ of $65 \%(\mathrm{v} / \mathrm{v})$ nitric acid in Teflon ${ }^{\circledR}$ microwave tubes and digested at $800 \mathrm{~W}$ and $220^{\circ} \mathrm{C}$ for 20 minutes using the Mars Xpress microwave system (CEM, Matthews, NC, USA). The digested

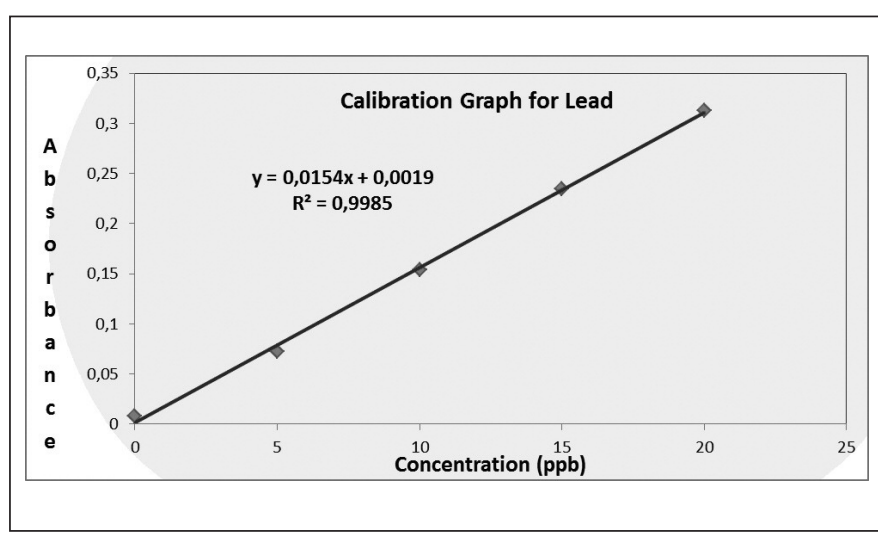

Fig 1. Calibration graph of lead, performed by graphite furnace atomic absorption spectrometry (GFAAS), equipped with Zeeman-effect background correction).

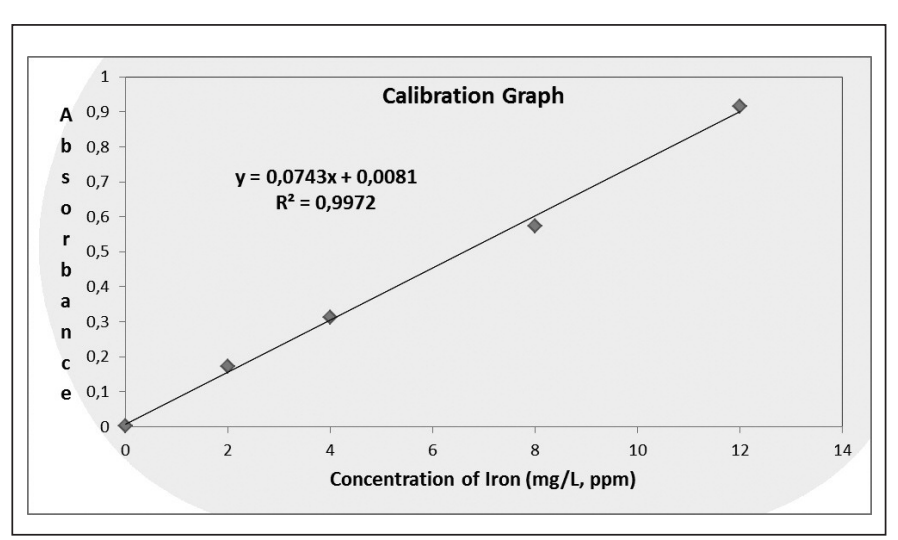

Fig 2. Calibration graph of iron, performed by flame atomic absorption spectrometry (FAAS). 
solutions were then diluted with $25 \mathrm{~mL}$ of ultra-pure water in 50-mL polypropylene tubes.

\section{Method Optimization}

For GFAAS determination of lead, the ashing and atomization temperatures in the graphite furnace were $400^{\circ} \mathrm{C}$ and $2100{ }^{\circ} \mathrm{C}$, respectively. Ammonium dihydrogen phosphate solution at the concentration of $5.0 \mathrm{mg} / \mathrm{mL}$ was utilized as the matrix modifier. Detection of lead was performed at the wavelength of $283.3 \mathrm{~nm}$ because of the better signal-to-noise ratio and lower background interferences than at the 219.0-nm line (19). For the FAAS determination of iron, the measurement time and delay time before reading were adjusted to $10 \mathrm{~s}$ and $5 \mathrm{~s}$, respectively. An air and acetylene flame were chosen with a flow rate of $2.0 \mathrm{~L} / \mathrm{min}$ and $13.5 \mathrm{~L} / \mathrm{min}$, respectively. The detection of iron was performed at the wavelength of $248.3 \mathrm{~nm}$ in a lean air-acetylene flame. The use of a lean air-acetylene flame helped to reduce the interferences. The instrumental operating parameters for the GFAAS and FAAS systems are listed in Table I.

\section{Validation}

Certified reference material (CRM) Seronorm ${ }^{\mathrm{TM}}$ Trace Elements Whole Blood L-2 (Sero AS, Billingstad, Norway) was analyzed 10 times using triplicate measurements to validate the method in terms of accuracy, precision, and recovery. The precision of the method was expressed as the relative standard deviation (\%RSD) of 10 indepen- dent analyses of the certified reference material. The results were compared with the certified values for accuracy, precision, and recovery of the method. Good agreement was obtained between the certified values and the measured concentrations. The certified lead content of the CRM was $336.0 \pm 18.0 \mu \mathrm{g} / \mathrm{L}$, while the measured value was $340.36 \pm 23.7 \mu \mathrm{g} / \mathrm{L}$, with the successful percent recovery and relative

\section{Atomic Spectroscopy \\ 1 Vol. 38(2), Mar./Apr.}

standard deviation (RSD) of 101.2\% and $6.96 \%$, respectively. Similarly, the certified iron content of the $\mathrm{CRM}$ was $12.3 \pm 1.0 \mathrm{mg} / \mathrm{L}$, while the measured value was $11.6 \pm 1.4 \mathrm{mg} / \mathrm{L}$, showed good recovery and relative standard deviation (RSD) of $94.30 \%$ and $9.48 \%$, respectively. The analytical results of the certified reference material study are summarized in Table II.

TABLE I

Operating Parameters for GFAAS and FAAS

\begin{tabular}{|c|c|c|}
\hline Element - matrix & Pb-Blood & Fe-Blood \\
\hline Instrument & Zeeman & Flame \\
\hline Concentration Unit & $\mu \mathrm{g} / \mathrm{L}$ & $\mathrm{mg} / \mathrm{L}$ \\
\hline Instrument Mode & Absorbance & Absorbance \\
\hline Sampling & Auto-Mix & Manuel \\
\hline Calibration Mode & Concentration & Concentration \\
\hline Measurement Mode & Peak Height & Peak Height \\
\hline Replicates Standard & 3 & 3 \\
\hline Replicate Sample & 3 & 3 \\
\hline Expansion Factor & 1.0 & 1.0 \\
\hline Wavelength & $283.3 \mathrm{~nm}$ & $248.3 \mathrm{~nm}$ \\
\hline Slit Width & $0.5 \mathrm{~nm}$ & $0.2 \mathrm{~nm}$ \\
\hline Gain & $44 \%$ & $75 \%$ \\
\hline Current & $10.0 \mathrm{~mA}$ & $5.0 \mathrm{~mA}$ \\
\hline Background & BC On & BC Off \\
\hline Standard 1 & $5.0 \mu \mathrm{g} / \mathrm{L}$ & $2.0 \mathrm{mg} / \mathrm{L}$ \\
\hline Standard 2 & $10.0 \mu \mathrm{g} / \mathrm{L}$ & $4.0 \mathrm{mg} / \mathrm{L}$ \\
\hline Standard 3 & $15.0 \mu \mathrm{g} / \mathrm{L}$ & $6.0 \mathrm{mg} / \mathrm{L}$ \\
\hline Standard 4 & $20.0 \mu \mathrm{g} / \mathrm{L}$ & $8.0 \mathrm{mg} / \mathrm{L}$ \\
\hline Reslope standard & Standard 2 & Standard 2 \\
\hline Recalibration Rate & 200 & 200 \\
\hline Calibration Algorithm & Linear & Linear \\
\hline Reslope Standard & Standard 2 & Standard 2 \\
\hline Recalibration Rate & 200 & 200 \\
\hline Calibration Algorithm & Linear & Linear \\
\hline
\end{tabular}

TABLE II

Analysis of Certified Reference Materials

\begin{tabular}{lccccc}
\hline $\begin{array}{l}\text { Seronorm } \\
\text { Trace Elements } \\
\text { Whole Blood L-2 }\end{array}$ & $\begin{array}{c}\text { Number of } \\
\text { Analytes } \\
(\mathrm{n})\end{array}$ & $\begin{array}{c}\text { Certified } \\
\text { Value }\end{array}$ & $\begin{array}{c}\text { Measured } \\
\text { Value }\end{array}$ & $\begin{array}{c}\text { Recovery } \\
(\%)\end{array}$ & $\begin{array}{c}\text { RSD } \\
(\%)\end{array}$ \\
\hline Lead & 10 & $336.0 \pm 18.0(\mu \mathrm{g} / \mathrm{L})$ & $340.36 \pm 23.7(\mu \mathrm{g} / \mathrm{L})$ & 101.2 & 6.96 \\
Iron & 10 & $12.3 \pm 1.0(\mathrm{mg} / \mathrm{L})$ & $11.6 \pm 1.70(\mathrm{mg} / \mathrm{L})$ & 94.30 & 9.48 \\
\hline
\end{tabular}




\section{Limit of Detection and Quantifi- cation}

The limit of detection (LOD) and lowest limit of quantification (LOQ) were determined based on the standard deviation of the response and the slope of the calibration curve based on the ICH guidelines (19, 20) $(\mathrm{LOD}=3.3 \sigma / \mathrm{S}, \mathrm{LOQ}=10 \sigma / \mathrm{S}$, where $\sigma$ is the standard deviation of the response and $\mathrm{S}$ is the slope of the calibration curve). All calculations were based on a blank reading. The GFAAS method for the lead analysis provided an LOD and LOQ equal to $0.43 \mu \mathrm{g} / \mathrm{L}$ and 1.42 $\mu \mathrm{g} / \mathrm{L}$, respectively. The FAAS method for iron analysis provided an LOD and LOQ equal to 3.30 $\mathrm{mg} / \mathrm{L}$ and $10.90 \mathrm{mg} / \mathrm{L}$, respectively.

\section{Statistical Analyses}

The Statistical Package for Social Sciences (SPSS) version 16.0 software for Windows ${ }^{\circledR}$ was used for the statistical analysis. All results were expressed as the mean \pm standard deviation (SD). Normality of data distribution was evaluated with the Kolmogorov-Smirnov test. The differences of the continuous variables between the two groups were evaluated by the student's $t$-test; the correlations between the parameters were interpreted using the Pearson's test. The statistical significance was considered as $\mathrm{p}<0.05$.

\section{RESULTS}

The results of the statistical analysis of lead and iron levels in the blood samples are listed in Table III. The mean blood iron level was significantly lower in beta-thalas-semia patients $(293.20 \pm 58.49 \mathrm{mg} / \mathrm{L})$ than in the controls $(405.28 \pm 111.14 \mathrm{mg} / \mathrm{L})$ $(\mathrm{p}<0.05)$. The mean blood lead level was significantly higher in beta-thalassemia patients $(71.20 \pm 43.38 \mu \mathrm{g} / \mathrm{L})$ than in the controls $(27.58 \pm 8.18 \mu \mathrm{g} / \mathrm{L})$ $(\mathrm{p}<0.05)$. In addition, a statistically negative correlation between iron and lead was detected in the betathalassemia patients $(r=-0.424$, $\mathrm{p}<0.05$ ).

\section{Discussion}

Beta-thalassemia is a major public health problem in the Mediterranean countries (1). It is considered to be one of the severest blood diseases because patients diagnosed with beta-thalassemia major are not able to generate sufficient healthy red blood cells. Therefore, they are entirely relying on lifelong blood transfusions (15). According to a study from Tadmouri et al. (21), the first two beta-thalassemia major patients in Turkey were reported in 1941 (22). It was not until 1971 that the overall prevalence of beta-thalassemia carriers in Turkey was reported and estimated to be $2 \%$ of the population (23).
Essential metals including copper, manganese, iron, and zinc are necessary for many critical physiological functions in humans. Thus, cells have developed several mechanisms to obtain these metals from their extracellular surroundings (24-26). Excess essential trace metals, in particular iron, are involved as causative agents in the extreme generation of free radicals and are able to cause oxidative damage to erythrocytes (27). For this reason, their concentrations in tissues and in the blood circulatory system are firmly regulated by diverse mechanisms (28). Toxic metals including lead, mercury, cadmium, and arsenic can be found both individually and as mixtures in different parts of the ecosystem (29). Nonessential toxic metals do not have any known specific function in an organism. However, they have an affinity to accumulate in the human body mainly by ingestion of food (30). Toxic metals interact with toxic and essential metals in different tissues (31). For instance, iron deficiency enhances absorption of cadmium, lead, and aluminum (32) and differences in the iron metabolism can alter lead toxicokinetics (33). Therefore, genes related to the iron metabolism can modify lead toxicity.

In the present study, blood iron and lead levels of beta-thalassemia patients were compared with healthy control subjects. It was found that beta-thalassemia patients

TABLE III Statistical Analysis of Lead and Iron Levels in Blood Samples of Thalassemia Patients and Control Groups

\begin{tabular}{|c|c|c|c|c|c|}
\hline Metals & Groups & Minimum & Maximum & Mean \pm S.D. & $\mathrm{p}$ value \\
\hline \multicolumn{6}{|c|}{ Lead $(\mu \mathrm{g} / \mathrm{L})$} \\
\hline & Thalassemia patients $(n=100)$ & 20.99 & 247.66 & $71.20 \pm 43.38$ & $<0.05$ \\
\hline & Controls $(n=100)$ & 12.27 & 48.92 & $27.58 \pm 8.18$ & \\
\hline \multicolumn{6}{|c|}{ Iron (mg/L) } \\
\hline & Thalassemia patients $(n=100)$ & 97.99 & 247.66 & $293.20 \pm 58.49$ & $<0.05$ \\
\hline & Controls $(n=100)$ & 134.09 & 755.45 & $405.27 \pm 111.11$ & \\
\hline
\end{tabular}


had statistically lower blood iron levels and higher blood lead levels than the controls $(p<0.05)$. One of the reasons that the mean blood iron levels of beta-thalassemia patients $(293.20 \pm 58.49 \mathrm{mg} / \mathrm{L})$ were found lower than from healthy controls $(405.28 \pm 111.14 \mathrm{mg} / \mathrm{L})$ was that the blood samples were obtained just before a red blood transfusion. Similarly, the reason why the mean blood lead level of beta-thalassemia patients $(71.20 \pm 43.38 \mu \mathrm{g} / \mathrm{L})$ was found higher than in healthy controls $(27.58 \pm 8.18 \mu \mathrm{g} / \mathrm{L})$ was related to an increased lead absorption when iron deficiency occurs. As for the healthy controls, the probable reason that the blood iron level was at normal levels (higher than for betathalassemia patients) was that they had no disease that would interact with their blood metal levels. It was also reported (34-39) that a high proportion of children born without beta-thalassemia and who have elevated blood lead levels also have low iron levels.

In addition, a statistically negative correlation between blood iron and lead was detected in the present study $(r=-0.424 ; p=0.001)$. This finding indicates that there can also be a relationship between blood lead and iron concentrations in beta-thalassemia patients. However, the mechanism whereby lead affects iron absorption is unclear. Some early studies offer a possible relationship between intestinal ferritin and iron (40). In other words, lead vies with iron for ferritin binding sites (41). Furthermore, the findings of the present study are consistent with several previous studies showing that iron-deficient anemia strengthens the absorption of lead $(42,43)$.

\section{CONCLUSION}

Spectral analysis is considered one of the most exact methods for the analysis of lead and iron in blood samples. The main goal and novelty of this paper was to compare the blood iron and lead levels of beta-thalassemia patients with healthy (non-thalassemic) control subjects in the Turkish population. A GFAAS method, equipped with Zeeman background correction, was developed for the determination of lead in blood samples, while blood iron levels were measured using FAAS. The proposed GFAAS and FAAS methods can be applied to routine toxicological blood lead and iron analysis.

On the basis of the measurements and statistical analysis, it was revealed that beta-thalassemia patients have lower blood iron levels and higher blood lead levels than the controls. Thus, it can be suggested that iron deficiency in beta-thalassemia patients is associated with higher blood lead levels. Consequently, the findings obtained from this study related to beta-thalassemia patients in Turkey will be a good reference for future studies of this disease by researchers in other nations.

\section{ACKNOWLEDGMENT}

The authors wish to thank the Scientific and Technical Research Council of Turkey (TUBITAK) for their financial support of this study under Project No. 114S312.

$\overline{\text { Received August 26, } 2016 .}$

\section{REFERENCES}

1. R. Galanello and R.Origa, Orphanet J. Rare. Dis. 5, 11 (2010).

2. G. Cighetti, L. Duca, L. Bortone, S. Sala, I. Nava, G. Fiorelli and M.D. Cappellini, Eur. J. Clin. Invest. 32 (Suppl 1), 55 (2002).

3. Y. Ginzburg and S. Rivella, Blood. 118(16), 4321 (2011).

4. M.E. Brandsma, A.M. Jevnikar and S. Ma, Biotechnol. Adv. 29(2), 230 (2011).
5. R. Evstatiev and C. Gasche, Gut. 61(6), 933 (2012).

doi:10.1136/gut.2010.214312 Downloaded from gut.bmj.com on April 22, 2014

6. H. Abdizadeh, A.R., Atilgan and C. Atilgan, J. Biol. Inorg. Chem. 20, 705 (2015).

7. M. Horvathova, P. Ponka and V. Divoky, Hematology 15(2), 96 (2010).

8. C. Eid, M. Hémadi, N.T. Ha-Duong and J.M. El Hage Chahine, Biochem. Biophys. Acta 1840(6), 1771 (2014).

9. A.R. Bijoor and T. Venkatesh, Indian J. Clin. Biochem. 22(2), 162 (2007).

10. J. Bierkens, R. Smolders, M. Van Holderbeke and C. Cornelis, Sci. Total Environ. 409, 5101(2011).

11. H.S. D'Souza, G. Menezes and T. Venkatesh, Indian. J. Clin. Biochem. 18, 154 (2003).

12. D. Tekin, Z. Kayaaltı and T. Söylemezoğlu, Int. Arch. Occup. Environ. Health 85, 631 (2012).

13. IARC (International Agency for Research on Cancer) Classified by the IARC Monographs, Vol. 1-102 (2012).

14. C.C. Bridges and R.K. Zalups, Toxicol. Appl. Pharmacol. 204(3), 274 (2005).

15. M.Z. Ferdaus, A.K. Hasan and H.U. Shekhar, J. Pak. Med. Assoc. 60(5), 360 (2010).

16. M.M. Uddin, S. Akteruzzaman, T. Rahman, A.K. Hasan and H.U. Shekhar, SRN Hematol. 2012, 659191. (2012). doi: 10.5402/2012/659191.

17. M.F. Karim, M. Ismail, A.M. Hasan and H.U. Shekhar, Int. J. Hematol. Oncol. Stem Cell Res. 10(1), 7 (2016).

18. S. Kumfu, S.C. Chattipakorn, S. Fucharoen and N. Chattipakorn, Life Sci. 150, 15 (2016).

19. B. Yüksel, Z. Kayaalti, D. KayaAkyüzlü, D. Tekin and T. Söylemezoğlu, At. Spectrosc. 37(3), 114 (2016).

20. International Conference on Harmonization (ICH) of Technical 
Requirements for the Registration of Pharmaceuticals for Human Use, Validation of Analytical Procedures: Methodology (ICBQ2B) (1996).

21. G.O. Tadmouri, N. Garguier, P.P. Dermont and A.N. Başak, Human Biology 73(5), 661 (2001).

22. M. Aksoy, Turk. J. Pediat. 33, 195 (1991).

23. A. Çavdar and A. Arcasoy, Acta Haemat. 45, 312 (1971).

24. E.J. Martinez-Finley, S. Chakraborty, S.J. Fretham and M. Aschner, Metallomics. 4(7), 593 (2012).

25. L. Ba, M. Doering, T. Burkholz and C. Jacob, Metallomics. 1(4), 292 (2009).

26. J.P. Bressler, L. Olivi, J.H. Cheong, Y. Kim, A. Maerten and D. Bannon, Hum. Exp. Toxicol. 26(3), 221 (2007).

27. N.M. Widad, L. Al-Naama and M.K Hassan, Haema. 6, 376 (2003).

28. A.J. Theron, G.R. Tintinger and R. Anderson, J. Clin. Toxicol. S3, 005 (2012).

29. Y. Liu, M.G. Vijver and W.G.M. Peijnenburg, Chemosphere 112, 282 (2014).

30. T. García-Barrera, J. Gómez-Ariza, M. González-Fernández, F. Moreno, M. García-Sevillano and V. GómezJacinto, Anal. Bioanal. Chem. 403, 2237 (2012).

31. V. Diacomanolis, B..N. Noller and J.C. Ng, Chemosphere 112, 203 (2014).

32. R.A. Goyer, Annu. Rev. Nutr. 17, 37 (1997)

33. S.K. Park, H. Hu, R.O. Wright, J. Schwartz, Y. Cheng, D. Sparrow, P.S. Vokonas and M.G. Weisskopf, Environ. Health Perspect. 117(1), 80 (2009).

34. A. Bradman, B. Eskenazi, P. Sutton, M. Athanasoulis and L.R. Goldman Environ. Health Perspect. 109, 1079 (2001).

35. N.M.H. Graham, R.B. Douglas and P. Ryan, Am. J. Epidemiol. 124, 389 (1986).

36. L. Taylor, B. Zuckerman, V. Harik and B. Mc Alister-Groves, J. Dev. Behav. Pediatr. 15, 120 (1994).

37. K.M. Sheehan, J.A. Di Cara, S. Le Bailly and K.K. Christoffel, Arch. Pediatr. Adolesc. Med. 151(5), 502 (1997).

38. J.K. Kiecolt-Glaser and R. Glaser, Stress and immune function in humans. In: R.

Psychoneuroimmunology II (Ader, R., Felten, D., Cohen, N., eds), Academic Press 849, San Diego, CA, USA (1991).

39. S. Cohen, D.A.J. Tyrell and A.P. Smith, New Eng. J. Med. 325, 606 (1991).

40. P.R. Flanagan, Acta Paediatr. Scand. Suppl. 361, 21 (1989).

41. J. Kochen and Y. Greener, Pediatr. Res. 9, 323 (1975).

42. A.A. Hegazy, M.M. Zaher, M.A, Abd El-Hafez, A.A. Morsy and R.A. Saleh, BMC Res. Notes. 3, 133 (2010).

43. J.W. Choi and S.K. Kim, Arch. Dis. Child. 88(9),791 (2003). 